\title{
Smart Business Strategy: Optimize the Role of Management Accounting
}

\author{
Yoga Tantular Rachman, Sendi Gusnandar Arnan, Yogo Heru Prayitno \\ Fakultas Ekonomi Universitas Widyatama \\ Bandung, Indonesia \\ yoga.tantular@widyatama.ac.id
}

\begin{abstract}
- this research purpose is to remind the role of management accounting for the business success. This research is using descriptive qualitative by studying literature method. The strategy is a key determinant of the success of a company in the long term that will ultimately make the company become winners in their respective industries. In fact, in all efforts to develop the company, business owners are always questions about how the company's current situation, where the company will be directed and how the company will achieve the goal. Recent techniques and shifts in the environment are often foreseen as leading management accountants to adopt a business orientation and strategies. Man agement accounting is able to provide various information to the manager or leader and also the owner. Specifically, management accounting identify, collect, measure, classify, and report information that is useful for internal users in planning, controlling, and making decisions, including determining the strategy to be taken by the company. Management accounting in this research will be very instrumental to the company strategies through the five pillars of power that can be generated by utilizing the management accounting information. This research is using descriptive qualitative by studying literature method.
\end{abstract}

Keyword: business strategy, management accounting, strategic management accounting.

\section{INTRODUCTION}

Every company needs to optimize business strategy, correctly manage the operation of the business and ultimately strengthen its future business prospecting to win competence. Companies need to understand that the strategy tends evolved from time to time due to circumstances and conditions change, so management need to improve the company's strategy continuously. In the discussion on what is meant by 'strategy' following matters need to be a concern: a) how to outperform competitors; b) how do companies react to changes in economic and market conditions whilst still seeking opportunities to grow; c) how to manage each functional unit of the business (such as research and development activities, supply chain, production, sales and marketing) and d) how to improve the financial performance of companies and markets [1]. Management need information from management accounting to reach companies goal.

Management accounting is a science that is often used as "stepchild " comparison financial accounting, so that many companies produce management accounting information comes from the company's financial accounting system.
Whereas the characteristics of the information in management accounting desired is very different from the characteristics generated by the financial accounting system. As a result many mistake in decision making of the company because it uses the information was not intended for such needs. One of the mistake that often made is to use the information production costs resulting from cost accounting system to make decisions [2].

Financial accounting system is a system that is designed on arrange of financial reports on outside parties of the company's, such as shareholders, creditors, taxes, and others. These financial statements should be prepared based on the rules defined in Statement of Financial Accounting Standards (SFAS)

Financial accounting system is a system that is designed to report the company's profit and the statement of financial position of the company. While for the management of the company, detail in system information is required, such as revenues, expenses, and income or loss per product or per customer. This information is needed to e.g. for make product or customer profitability analysis, cost efficiency analysis, pricing analysis, etc [3].

The cost of the financial information system of the company has recorded separately acquired company's revenue for each product or customer. But so is the same thing does not happen at any cost or expense recording companies. In this case, the costs incurred by the company can be divided into two parts, the direct costs and indirect costs. The direct costs are the costs that can be traced accurately the costs of each object. Cost object is the "place" where these costs will be borne. Cost objects can be products, customers, departments, activities, and so forth. In this study, it will be assumed that the object is the cost of the product. Because of the direct costs are costs that may be charged accurately on each of the products produced by the company. Examples of direct costs are direct materials, direct labor and cost [3].

The other category is the indirect costs. These are costs that are used together for the overall products produced or sold by the company. These costs in financial accounting systems companies not accounted for separately per product, but accounted for the company as a whole, because basically there is no urgency for companies to record these costs in detail for each of the products, because of financial accounting systems are designed to report the company's overall costs. Problems 
arise kertika company wants to know the cost for each product. Because the cost of the company's overall figures, so to determine the number of each product costs, the company will perform the cost allocation [2]. Basic allocation of indirect costs used biasaynya company are: 1) production unit; 2) units sold; 3) direct labor hours; 4) the cost of direct labor; 5) the cost of direct materials and 6 ) hours of the machine [3].

Cost allocation is done on the basis of the allocation will lead to inaccurate results, because each different allocation basis will produce different allocation figures. Thus, if the company has only one information system, the financial information system, then the system will generate good information to parties outside the company, but not so with the accounting information to the parties in the company.

The second thing is that the problem is the submission of the company's financial statements. Many companies are now able to produce financial statements (statement of financial position, statement of comprehensive income, and cash flow statement) on a monthly basis. Things like that it looks good, but it was insufficient to kebutuhna management accounting information. Accounting information reported on a monthly basis is not a good thing to provide information for management. If managers only get accounting information on a monthly basis, it is likely that the actual information about the opportunity can benefit companies already become stale when the company knows it. The same applies to threats facing the company. At the time the threat was known, could already be a big problem for the company. Not to mention the problems associated with the feedback. It would be ironic if the feedback regarding a step made by a new company known to one month or one quarter later. This is clearly seen in the concept of analysis of variance in the topic of the standard cost [3]. Due to these reasons, the management accounting information system requires the accounting information system that can provide information as soon as possible, ideally even a system such information can be presented in real -time .

Most of research on management accounting roles focuses on studying their individual characteristics. Survey of management accounting in both the USA [4] and the UK [5] indicate a broadening of roles and the importance of both analytical and social skill in these roles. [6] Argues that management accounting can live up to demand for more proactive involvement and role inovation as long as they possess or can develop learning goal oreintation.

\section{LITERATURE REVIEW}

Strategic management is a relatively new field of science and modern, which introduced both in the corporate world as well as being an important academic study after it was discovered that the strategic management became one of key determinant success of a company in the long term. It becomes an important thing, because the company's goal is not just to generate profits but also the sustainability of the company. [1] There are five stages in the preparation and implementation of strategies: 1) develop a strategic vision of the company's basic direction of the long term, set a mission to describe the company's objectives and determining the values as a guide in the pursuit of the vision and mission of the company; 2) determine the objectives to benchmark progress and performance of the company; 3) develop a strategy to achieve the goal and pushed the company to the strategic phase has been prepared by management; 4) implement the strategy that has been effectively and efficiently and 5) to monitor any developments, evaluate each performance and make adjustments that are corrective in the vision and mission, goals and strategies of the company. Management accounting as an information system provide major information to support business strategic.

Management accounting is a profession that involves partnering in management decision making, devising planning and Performance management systems, and providing exper tise in financial reporting and control to assist management in the formulation and implementation of an organization's strategy [7]. Accounting management system is an enterprise accounting system designed to provide information to the manager of the company, so they can perform their activities and strategies better, because the information management accounting system does not need to follow certain rules for the information useful for managers.

The management accounting system focuses increasingly more to activities to be undertaken at all organizational levels. Assessment, management and continuous improvement of these activities are critical to the success of a company. Management accounting is able to "add value" to a business, through the following five major goals: 1) providing information for decision making and planning, and proactively participating as part of management team in decision-making and planning processes; 2) assisting managers in directing and controlling operational activities; 3) motivating managers and other employees toward the organizational's goal; 4) measuring the performance of activities, subunits, managers and other employees within the organization and 5) assessing the organization's competitive position and working with other managers to ensure the organization's long-run competitiveness in its industry [8]. It can be noticed from this panel of the management accounting objectives a clear orientation towards the management activity and to on going collaboration with it, in order to achieve the company's strategic objectives, coordinating and controlling permanently the current (daily) activities.

The IMA's Foundation for Applied Research (FAR) committee in developing the definition focused on three important components of management accounting. In order of priority, they were: 1) management accounting's essential component is the formulation and implementation of strategy to help an organization succeed. This component states in broad terms the role of the management accountant. In a more detailed sense, the component states that every management accountant, at whatever point on the information value chain he or she may be, contributes to the organization's success through the implementation of strategy; 2) to accomplish the above, management accountant's work within management teams. This component reflects research and practice that indicates management accountant's work as part of management teams at all levels of the information value chain, which includes participation in strategic management decision making and 3 ) the role of management accountants on the 
management team can be described by a brief list of global, inclusive competencies [9]. This component is necessary to spell out how the management accountant can be differentiated from other professionals in the organization since the implementation of strategy by management teams can be associated with any management professional in the organization. The choice of which competencies to include in the definition in order to differentiate management accountants was guided by the predetermined criteria listed above: The definition should be succinct, global, timeless, inclusive, and forward-looking. Some of the responses to the exposure draft expressed concern regarding the extent of the management accountant's involvement in the formulation and execution of strategy.

\section{METHODOLOGY}

The design of this research is descriptive qualitative by studying literature. Descriptive method is a method used to examine the status of human groups, an object, a state and a system of thought as well as events that will occur [10]. The purpose of a descriptive study is to make exploratory picture or painting in a systematic, factual and accurate information on the facts, nature and the relationship between the various symptoms that will be studied.

\section{RESULTS AND DISCUSSION}

In principle a good strategy with the execution of that good strategy it's mean good management. Thus that actually build and execute a strategy is the most fundamental management functions. In other words, of all the things that are run by the management there is nothing more fundamental influence on the successful culmination of a company than on how the management team map the direction in which the company will be taken. Management accounting provide information that will be need by management to map the direction. Such information can be provided only if the management accounting information systems available and implemented well in the company. The five pillars of the strength of management accounting is achieve sustainable competitive advantage, cost leadership, differentiation and focus strategy, applying the concept of value chain and strategic cost analysis.

Management accounting is the one that provides financial and operational information needed by managers in order to achieve the strategic objectives of the organization [11]. By nature management accounting is a measurement process; the scope of management accounting includes financial information, such as cost, and operational information, such as percentage of defective units produced; the purpose of management accounting is to help an organization reach its key strategic objectives. It is not meant for mandated financial and tax reporting purposes.

Although the costs computation remains an important objective of management accounting, it must be emphasized the importance of designing and developing a management accounting system oriented to achieving the strategic objectives of the organization. If until recent, the managers" decisions aimed at achieving increased short term results, by maximizing profits, in detriment of the actions that generate long-term effects, in our opinion is essential to reconsider the objectives of management accounting, so that information generated by it to be useful for an organization in its efforts of creating value and ensuring long-term success.

Management accounting information have different characteristics of financial accounting information, so the information is supposed to be produced by two different systems. One model that can be used to develop a management accounting system is activity-based costing (ABC). The purpose of $\mathrm{ABC}$ is to charge indirect costs more accurately. This system gives a more accurate picture and details about the state of the company, such as the profitability of the product or the company's customers.

According to [1], ABC information can be used for two things. First, ABC information is used to indicate activities that are not efficiently carried out by the company, which has a great cost, which in turn reduces the profitability of the product or the company's customers. With ABC information, the company can take action against inefficient activities, so that the company's operations can be conducted more efficiently and improve profitability.

Second, information systems $\mathrm{ABC}$ can be used as a basis for making better strategic decisions for the company. ABC system will generate accurate information, which led to the company or the customer can find products which are unbeneficial or beneficial, so the company can take more accurate decisions on actions to be carried out on the product or the customer.

Diversity of products or services, but also of customers, generates the increase of the complexity of the undertaking activities. In this context, it is necessary the - rethinking\| of whole production process and the abandon of traditional processes. It must renounce to the vertical "guiding" and move to a transversal approach, through value chain.

Each firm must be seen in the context of a general chain of value creation. Value chain analysis is essential in determining exactly what factors can lead to the improvement of value and / or to reduce costs. For this reason, one must be understood the entire chain, not only that part at which the company takes part.

As illustrated by the assertion of strategic management accounting techniques, the adoption of an activity-based costing system can be at hand and solid approach, while supporting the strategic decision-making process of an entity. $\mathrm{ABC}$ system, besides the fact that provides a more accurate cost, also provides useful information to managers not only regarding the cost of products/ services or the profit generated, but also for decisions making regarding the issues that the enterprise face outside its boundaries, a particularly important fact in a competitive economy. Effective implementation of activity-based costing often depends on behavioral factors rather than technical ones, because the involvement of the entire staff is essential for the success of this process.

Losing the relevance of the information provided by management accounting was not necessarily caused by improper use of the information in managing the business, as especially by inappropriate use in operational control. The 
activity-based costing eliminated many problems that have made that cost information irrelevant for planning and decision making.

The decisions that have to be made in order to ensure effective resources allocation requires a variety of information that only management accounting can make available to managers. The role of management accounting changed over time, depending on the economic context. Of course, in a complex, turbulent and uncertain environment, the managers information needs are diversifying and growing, and management accounting - as a privileged source of information for the management system - can meet these requirements, provided that permanently adapt its tools and practices to the requests of decision-makers.

Management accounting performs a similar function for individuals in an organization. It provides operational and higher management with the information that helps them do their job and achieve the quality, cost, and time objectives of the organization. Management accounting information helps managers achieve quality goals by measuring and reporting the resources used in preventing defects; the cost of reworking defective units; the cost of doing warranty repairs; lost sales from selling poor quality products; new investment needed for increasing product quality; and by determining whether the spending on quality is producing tangible financial benefits [12]. Examples of information that helps managers attain the strategic objective of cost management include reporting resources consumed by the products produced during a period; measuring resources consumed by activities performed in a period; analyzing factors that drive or cause costs to be incurred; analyzing product profitability; analyzing suppliers' cost structures; and comparing (benchmarking) their cost against competitors' costs. Management accounting helps attain the strategic objective of time by measuring and reporting lost sales and profits from late product introductions; costs of delayed deliveries from suppliers; sales from new versus old products; response time to ship customer orders; and unused capacity available for new product

\section{CONCLUSION}

The fundamental purpose of management accounting is to help an organization achieve its strategic objectives. Meeting these objectives satisfies the needs of its customers and other stakeholders. Typical stakeholders include shareholders, creditors, suppliers, employees, and labor unions.

Strategy is the way that a firm positions and distinguishes itself from its competitors. Positioning refers to the selection of target customers or markets. Distinctions are made on the three dimensions of quality, cost, and time. Different customers have different expectations about the features and performance reliability (quality) they want in a product, the price (cost) they are willing to pay, and when and how quickly they want the product or services delivered (time). Management-accounting systems report the results of operations using financial and nonfinancial measures.

Results the necessity of linking the information provided by management accounting with entity's goals, only this way management accounting being a useful tool in decision making. Given the new requirements related to restructuring the entire enterprise"s activity, its managers raise the question of whether the information provided by the traditional accounting system can successfully meet these requirements. For management accounting is born a new challenge, to optimize the entity's offer, adapting products or services costs to the value it represent for the client. Information provided to managers should assist them in determining the optimal products / services mix that will be manufactured and sold as well as the profit generated by each product or service.

\section{REFERENCES}

[1] Atkinson, Anthony A., Kaplan, Robert S., Matsumura, Ella Mae, and Young S. Mark. 2012. Management Accounting; Information Decision Making and Strategy Execution. 6th edition, Pearson Education.

[2] Cooper, Robin and Kaplan, Robert S. (1999). The Decision of Cost Management System; Text and Case. 2nd Edition, Prentice Hall.

[3] Hansen, Don R., and Mowen, Maryanne M., and Guang, Liming. 2009. Cost Management. 6th edition, South Western Cengage Learning.

[4] Siegel, G., and Sorensen, J.E. (1999). Counting More, Counting Less Transformations in the Management Accounting Profession. Institute of Management Accountants, p. 101.

[5] Burns, J., and Yazdifar, H. (2001) 'Tricks or Treat, Featuring Changing Role of Accountants'. Financial Management, pp. 33-35.

[6] Coad, A.F. (1999) 'Some survey evidence on the learning and performance orientations of management accountants'. Management Accounting Research, 10, pp. 109-135.

[7] Institute of Management Accountant. 2008. Practice of Management Accounting. Copyright $\odot 2008$ in the United States of America.

[8] Hilton, R.W. (2005) Managerial accounting: creating value in a dynamic business environment, 6th edition, Boston: Mc Graw Hill.

[9] IMA's Foundation for Applied Research (FAR) committee (2007)

[10] Sugiyono. 2010. Metode Penelitian Bisnis. Cetakan Kesepuluh. Alfabeta: Bandung.

[11] Bell, J., Anshari S., Klammer T., and Lawrence C. 2004. Strategy and Management Accounting. Module version 1.2, Copyright@ Houghton Mifflin Company.

[12] Carmen, Almasan A. and Corina G. 2008. A Strategic Approach of Management Accounting. JEL code: M41, M10. 